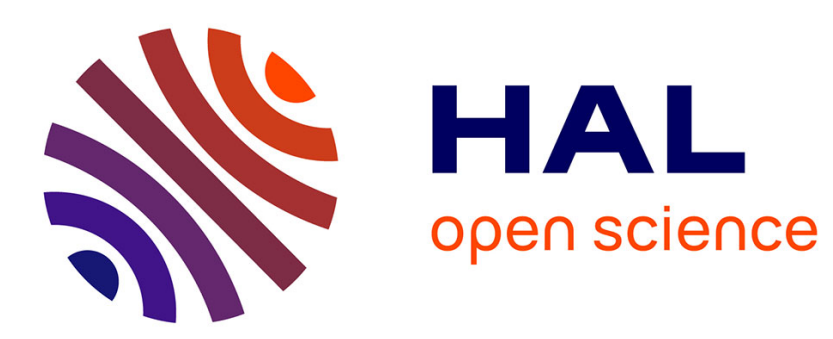

\title{
Facile Access via Green Procedures to a Material with the Benzodifuran Moiety for Organic Photovoltaics
}

Chady Moussallem, Olivier Segut, Frédéric Gohier, Magali Allain, Pierre Frère

\section{To cite this version:}

Chady Moussallem, Olivier Segut, Frédéric Gohier, Magali Allain, Pierre Frère. Facile Access via Green Procedures to a Material with the Benzodifuran Moiety for Organic Photovoltaics. ACS Sustainable Chemistry \& Engineering, 2014, 2, pp.1043-1048. 10.1021/sc500042u . hal-03347287

\section{HAL Id: hal-03347287 \\ https://univ-angers.hal.science/hal-03347287}

Submitted on 17 Sep 2021

HAL is a multi-disciplinary open access archive for the deposit and dissemination of scientific research documents, whether they are published or not. The documents may come from teaching and research institutions in France or abroad, or from public or private research centers.
L'archive ouverte pluridisciplinaire HAL, est destinée au dépôt et à la diffusion de documents scientifiques de niveau recherche, publiés ou non, émanant des établissements d'enseignement et de recherche français ou étrangers, des laboratoires publics ou privés. 


\title{
Süstalinable Chemistry\& Engineering

\section{Facile Access via Green Procedures to a Material with the Benzodifuran Moiety for Organic Photovoltaics}

\author{
Chady Moussalem, Olivier Segut, Frédéric Gohier, Magali Allain, and Pierre Frère*
}

University of Angers, MOLTECH-Anjou UMR CNRS 6200, SCL group, 2 boulevard Lavoisier, 49045 Angers cedex, France

Supporting Information

ABSTRACT: The synthesis by following green approaches of a new material based on benzodifuran and bithiophene units connected by azomethine junctions is described. X-ray structure analysis revealed a strong $\pi-\pi$ stacking of the molecules in the solid state. The electronic properties were investigated by using UV-vis spectroscopy and cyclic voltammetry. This environmentally friendly material has been evaluated as a donor material in basic bilayer heterojunction solar cells by using $\mathrm{C}_{60}$ as the acceptor material to afford a power conversion efficiency superior to $1 \%$.

KEYWORDS: Green chemistry, Organic photovoltaic, Benzodifuran, Azomethine

\section{INTRODUCTION}

Work on clean and renewable energy sources is at the forefront of global research to answer the always increasing energy demand and environmental concerns caused by fossil energy consumption. Solar energy appears as an interesting possibility to produce clean electrical energy by photovoltaic cells. ${ }^{1}$ Silicon-based solar cells that are predominant on the market have a non-negligible environmental impact. Other technologies such as organic photovoltaic cells (OPV) based on organic semiconductors offer the possibility to develop effective solar cells that aim to have a lower environmental impact. ${ }^{2-6}$ Nevertheless the synthetic procedures for the conception of organic semiconductors are essentially based on organometallic coupling or Wittig type reactions producing toxic byproducts for environment. ${ }^{7}$ On the other hand, it has been demonstrated that traces of metal impurities in the resulting semiconductors strongly affected the performance of the devices. ${ }^{8}$ Thus, the necessary high purifications of the resulting polymers or molecules are laborious and use large amounts of solvent without ensuring the high level of purity required for the semiconductors. Two recent articles focused on the environmental impact of the various synthetic procedures used for the development of materials for OPV and discussed the first examples of synthesis employing green chemistry concepts., ${ }^{9,10}$ Direct (hetero)arylation reactions that allow for avoiding organometallic coupling reactions for the synthesis of small molecules or for the polymerization processes of active materials have been recently developed with the idea to decrease the environmental impact of making organic semiconductors. ${ }^{11-14}$ Other possibilities consist of using condensation reactions such as Knoevenagel reactions or Schiff base reactions for developing extended conjugated systems via ethylenic or azomethine junctions. Materials based on cyano vinyl units have been developed for the synthesis of low band gap materials ${ }^{15,16}$ and are known to present high electronic affinity leading to n-type organic transistors with high electronic mobility. ${ }^{17,18}$ Azomethine bonds that are isoelectronic of ethylenic bonds ${ }^{19,20}$ have been used to develop conjugated materials for different applications such as electrochromic materials, ${ }^{21,22}$ emissive polymers, ${ }^{23,24}$ photocatalytic water splitting, ${ }^{25}$ and $\mathrm{OPV}^{26,2}$

On the other hand, benzo[1,2-b:4,5- $\left.\mathrm{b}^{\prime}\right]$ difuran $(\mathrm{BDF})^{28}$ units (Chart 1 ) diversely substituted on the central benzenic core $\left(R_{1}\right)$ or on positions $2\left(R_{2}\right)$ or $3\left(R_{3}\right)$ of the furan cycles have been exploited for the development of conjugated materials to build organic light emission diodes (OLEDs) ${ }^{29-32}$ or OPVs. ${ }^{33-41}$ In general, the syntheses of the BDF units and then the extension of the conjugated systems require several steps in hard conditions often using organometallic reactions. The global yields to reach the conjugated materials used in OPV cells are inferior to $10 \%$.

In this context, we have focused on the development of conjugated materials synthesized and purified via green approaches. ${ }^{42}$ In the first example, we show that compound BDF-T $\mathbf{2}_{2}$, which associates benzodifuran and bithiophene units connected by azomethine bonds and is easily synthesized in two steps and purified by simple recrystallization, is an active donor material in basic bilayer BDF-T $\mathbf{T}_{2} / \mathrm{C}_{60}$ solar cells.

\section{EXPERIMENTAL SECTION}

Synthesis. Diamino BDF 3 was synthesized as already described. ${ }^{43}$ Aldehyde 4 can be obtained from 2-bromo-5-hexylthiophene in two steps $^{44,45}$ or in one step by direct arylation between 2-carbaldehydethiophene and 2-bromo-5-hexylthiophene. ${ }^{13}$

BDF- $T_{2}$. Aldehyde $4(580 \mathrm{mg}, 2.1 \mathrm{mmol})$ and a catalytic amount of $\mathrm{P}_{2} \mathrm{O}_{5}(15 \mathrm{mg}, 5 \% \mathrm{~mol})$ were successively added to a solution of 3 (520 $\mathrm{mg}, 1 \mathrm{mmol}$ ) in $10 \mathrm{~mL}$ of ethyl lactate at room temperature. After $8 \mathrm{~h}$ of stirring, the solution was poured in a mixture of $100 \mathrm{~mL}$ of watermethanol $(50-50 \mathrm{vol})$ to give a red precipitate. After filtration, the

\footnotetext{
Received: January 20, 2014

Revised: February 24, 2014

Published: February 25, 2014
} 
Chart 1. Structures of BDF Unit and Compound BDF-T

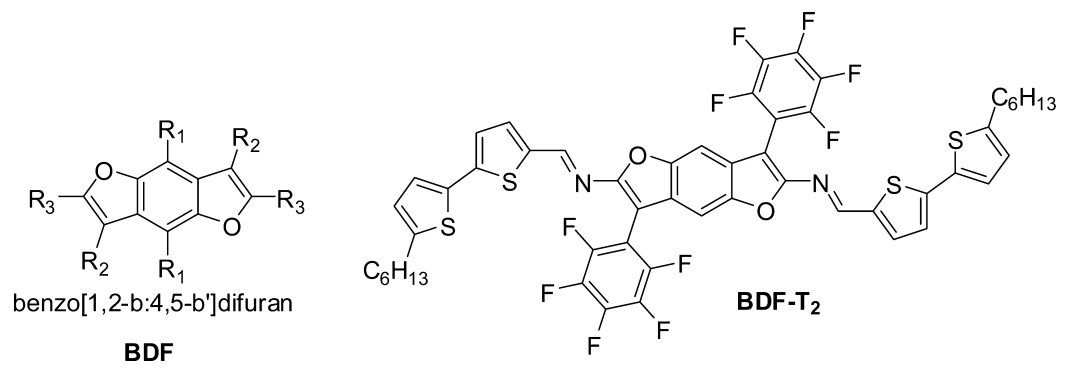

solid was recovered, washed with $20 \mathrm{~mL}$ of methanol, dried under vacuum, and then recrystallized from ethyl acetate solution.

Red solid: $720 \mathrm{mg}$. Yield: $70 \%$. Mp: $200{ }^{\circ} \mathrm{C} .{ }^{1} \mathrm{H}$ NMR $\left(\mathrm{CDCl}_{3}\right)$ : $8.80(\mathrm{~s}, 2 \mathrm{H}), 7.35(\mathrm{~d}, 2 \mathrm{H}, J=3.7 \mathrm{~Hz}), 7.14(\mathrm{~d}, 2 \mathrm{H}, J=3.5 \mathrm{~Hz}), 7.03$ $(\mathrm{d}, 2 \mathrm{H}, J=3.7 \mathrm{~Hz}), 6.72(\mathrm{~d}, 2 \mathrm{H}, J=3.7 \mathrm{~Hz}), 2.81(\mathrm{t}, 4 \mathrm{H}, J=7.5 \mathrm{~Hz})$, $1.70(\mathrm{~m}, 4 \mathrm{H}), 1.34(\mathrm{~m}, 12 \mathrm{H}), 0.91(\mathrm{t}, 6 \mathrm{H}, 6.6 \mathrm{~Hz}) .{ }^{13} \mathrm{C}$ NMR $\left(\mathrm{CDCl}_{3}\right): 154.8,151.0,149.1,147.9,145.2,140.3,135.4,134.2,127.1$, 125.4 (2), 123.9, 101.2, 100.7, 31.6, 31.5, 30.3, 28.8, 22.6, 14.1. ${ }^{19} \mathrm{~F}$ NMR $\left(\mathrm{CDCl}_{3}\right):-139.3(\mathrm{dd}, 4 \mathrm{~F}, J=6.8 \mathrm{~Hz}, J=22.4 \mathrm{~Hz}),-157.0(\mathrm{t}$, $2 \mathrm{~F}, J=22.4 \mathrm{~Hz}),-164.7(\mathrm{td}, 4 \mathrm{~F}, J=6.8 \mathrm{~Hz}, J=22.4 \mathrm{~Hz})$. Mass (MALDI-TOF): $\mathrm{C}_{52} \mathrm{H}_{38} \mathrm{~F}_{10} \mathrm{~N}_{2} \mathrm{O}_{2} \mathrm{~S}_{4}$; Calcd, 1040.2; Found, 1041. Anal. $\mathrm{C}_{52} \mathrm{H}_{38} \mathrm{~F}_{10} \mathrm{~N}_{2} \mathrm{O}_{2} \mathrm{~S}_{4}$ Calcd C, 59.90; H, 3.68; N, 2.69; S, 12.32. Found: C, 59.59; H, 3.59; N, 2.70; S, 12.03 .

Crystal Data and Structure Refinement. Single crystals of BDF$\mathrm{T}_{2}$ suitable for X-ray diffraction analysis were obtained by slow evaporation of a mixture of chlorobenzene-dichloromethane solution. The compound co-crystallizes with two molecules of chlorobenzene in the triclinic $P-1$ space group. The structure is defined from a half of molecule of BDF-T $\mathbf{T}_{2}$ and a molecule of solvent that lies on the inversion center.

$\mathrm{X}$-ray single-crystal diffraction data were collected at $293 \mathrm{~K}$ on a BRUKER KappaCCD diffractometer, equipped with a graphite monochromator utilizing Mo $\mathrm{K} \alpha$ radiation $(\lambda=0.71073 \AA)$. The structure was solved by direct methods and refined on $\mathrm{F}^{2}$ by the fullmatrix least-squares method using the SHELX $97^{46}$ package. All non-H atoms were refined anisotropically, and absorption was corrected by the SADABS program ${ }^{47}$. The $\mathrm{H}$ atoms were included in the calculation without refinement.

Crystallographic Data for BDF-T $2+2 \mathrm{C}_{6} \mathrm{H}_{5} \mathrm{Cl}$. $\mathrm{C}_{64} \mathrm{H}_{48} \mathrm{Cl}_{2} \mathrm{~F}_{10} \mathrm{~N}_{2} \mathrm{O}_{2} \mathrm{~S}_{4}, M=1266.18$, red plate, $0.33 \times 0.21 \times 0.05$ $\mathrm{mm}^{3}$, triclinic, space group $P-1, a=7.8744(5) \AA, b=12.380(1) \AA, c=$ 16.243(2) $\AA, \alpha=79.22(1)^{\circ}, \beta=83.45(1)^{\circ}, \gamma=77.62(1)^{\circ}, V=$ $1514.8(2) \AA^{3}, Z=1, \rho$ calc $=1.388 \mathrm{~g} / \mathrm{cm}^{3}, \mu($ Mo K $\alpha)=0.321 \mathrm{~mm}^{-1}$, $\mathrm{F}(000)=650, \theta \min =3.31^{\circ}, \theta \max =27.1^{\circ}, 17897$ reflections collected, 6346 unique $\left(R_{\text {int }}=0.08\right)$, parameters $/$ restraints $=380 / 1$, $\mathrm{R} 1=0.0865$ and $\mathrm{wR} 2=0.1620$ using 2705 reflections with $\mathrm{I}>2 \sigma(\mathrm{I})$, $\mathrm{R} 1=0.2135$ and $\mathrm{wR} 2=0.2158$ using all data, $\mathrm{GOF}=1.031,-0.366<$ $\Delta \rho<0.286$ e. $\AA^{-3}$. CCDC- 970553 .

\section{RESULTS AND DISCUSSION}

The synthetic pathway of compound BDF-T $\mathbf{T}_{2}$ is based on two eco-friendly condensation reactions giving only water as waste (Scheme 1). The diamino compound 3 is easily obtained in $45 \%$ yield by cascade reactions between benzoquinone 1 and pentafluorophenyl acetonitrile $\mathbf{2}$ in the presence of aqueous ammoniac solution or $\mathrm{Et}_{3} \mathrm{~N}$ in ethanol. ${ }^{43}$ After precipitation and washing with ethanol, compound $\mathbf{2}$ is directly engaged in a second step with bithiophene carbaldehyde 4 . The green method using ethyl lactate as solvent ${ }^{48,49}$ at room temperature in the presence of a catalytic amount of trifluoroacetic acid (5\% mol) or a little amount of $\mathrm{P}_{2} \mathrm{O}_{5}(\approx 5 \% \mathrm{~mol})$ led to compound BDF-T $\mathbf{T}_{2}$ in $70 \%$ yield after precipitation in water. Recrystallization in ethyl acetate gives the purity required to use BDF-T $\mathbf{T}_{2}$ as
Scheme 1. Synthesis of Compound BDF-T

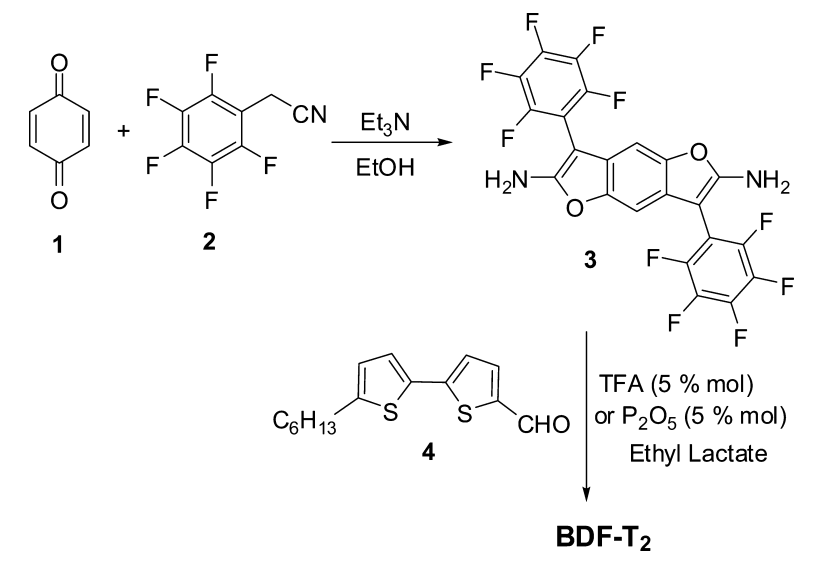

organic semiconductor materials in a global yield of $30 \%$ for the two steps.

In terms of green chemistry, the atom economy ( $\mathrm{AE}$ ) for the synthesis of BDF-T $\mathbf{T}_{2}$ is of $96.4 \%$ because only water is produced as a secondary product. Nevertheless, the yields of each step have to be considered taking into account the amount of produced waste. Thus, the experimental AE for the synthesis of BDF-T $_{2}$ is of $30 \%$. For comparison, synthetic processes of $4,8-$ disubstituted benzodifuran units involving donor-acceptor copolymers for organic solar cells have experimental $\mathrm{AE}$ around $8-9 \%{ }^{35,36}$ After the coupling reactions to build the conjugated systems, the experimental AE may fall below 5\%. For a better understanding of the impact of the synthetic procedures on the environment, Sheldon proposed the term E factor (mass of waste per mass of product) to take into account of the actual amount of waste produced in the process. ${ }^{50,51}$ Recently, Osedach et al. calculated the amount of waste produced for the synthesis of OPV materials, polymers, and small molecules for demonstrating the importance of the synthetic routes to develop the conjugated materials. ${ }^{9}$ From determined criteria, the amount of waste, including workup and purification operations and solvent, for the different synthetic steps was calculated. On this basis, it was calculated that P3HT has an E factor of 430, while copolymers based on dioctylbenzodithiophene and thienothiophene units could reach $E=4729$.

The E factor corresponding to the synthesis of $\mathbf{B D F}-\mathbf{T}_{2}$ has been calculated by using the same criteria. The syntheses of available benzoquinone $\mathbf{1}$ and pentafluorophenyl acetonitrile $\mathbf{2}$ have not been considered (see the Supporting Information for the calculation). The access to BDF- $\mathbf{T}_{\mathbf{2}}$ from compounds $\mathbf{1}, \mathbf{2}$, and 4 gives $E=204$ without taking into account the wastes produced for the synthesis of aldehyde 4 . This latter can be prepared in three steps from 2-hexylthiophene by a 


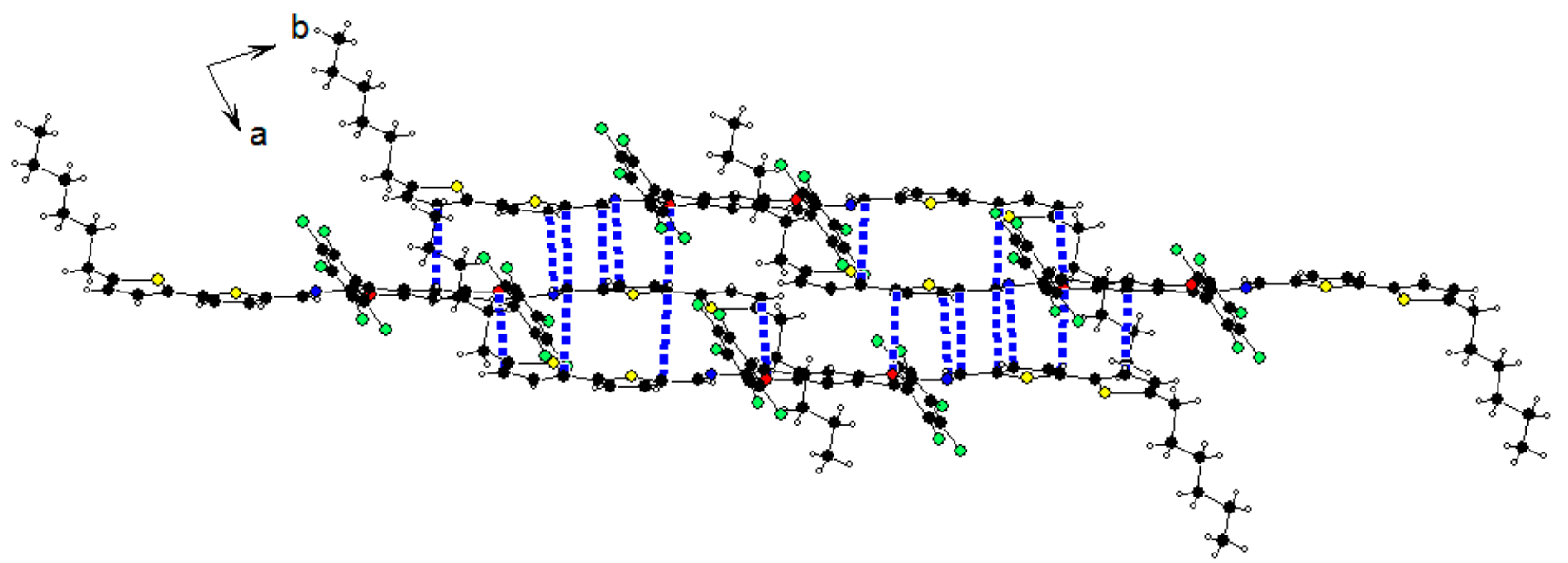

Figure 1. X-ray structure of BDF-T $\mathbf{2}_{2}$ showing the stacking and contacts between the molecules (blue dotted lines).

Table 1. Electrochemical ${ }^{a}$ and Optical Data ${ }^{b}$ of BDF-T

$\begin{array}{ccccccccc}E_{\text {ox }}(\mathrm{V}) & E_{\text {red }}(\mathrm{V}) & \mathrm{HOMO}^{c}(\mathrm{eV}) & \mathrm{LUMO}^{c}(\mathrm{eV}) & \Delta E_{\text {elect }}(\mathrm{eV}) & \lambda_{\max }(\mathrm{nm}) & \varepsilon \mathrm{L} \mathrm{mol}^{-1} \mathrm{~cm}^{-1} & \Delta E_{\text {opt }}(\mathrm{eV}) & \Delta E_{\text {film }}(\mathrm{eV}) \\ 0.99 & -1.49 & -5.87 & -3.79 & 2.08 & 490, \underline{527}, 570 & 71000 & 2.10 & 1.80\end{array}$

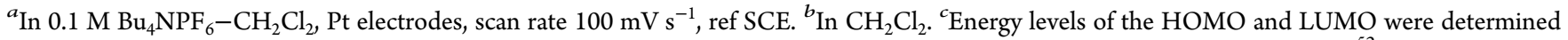
from the onset of the oxidation and reduction waves, respectively, by using an offset of $4.99 \mathrm{eV}$ for the SCE vs vacuum level. ${ }^{52}$

bromination followed by a coupling with $\mathrm{ThMgBr}^{45}$ and then a formylation with the sequence $\mathrm{BuLi} / \mathrm{DMF}{ }^{44}$ as indicated in the Supporting Information. By considering the synthesis of $\mathbf{4}$, the $\mathrm{E}$ factor for $\mathbf{B D F}-\mathrm{T}_{2}$ rises to $E=1194$. This calculation demonstrates the strong impact of the synthesis of the aldehyde. In order to decrease the E factor, a greener method based on the direct arylation between thiophene carbaldehyde and 2-bromo-5-hexylthiophene has been evaluated by adapting the procedure described by Fagnou et al. ${ }^{13}$ The $\mathrm{E}$ factor for the synthesis of 4 decreases from $E=1345$ with the first method to $E=903$ for the direct arylation, thus allowing the $\mathrm{E}$ factor to reach $E=858$ for the preparation of BDF- $\mathbf{T}_{2}$. It is important to note that the synthetic procedures from 2-hexylthiophene do not generate any highly toxic stannane waste.

The structure of $\mathbf{B D F}_{\mathbf{2}} \mathbf{T}_{\mathbf{2}}$ has been confirmed by X-ray diffraction analysis of single crystals. The bithiophene unit and the azomethine junctions in an E configuration are in the plane defined by the benzodifuran system (Figure S3, Supporting Information). The two lateral perfluorophenyl groups are not coplanar with the conjugated systems assuming a torsional angle of $57^{\circ}$ with respect to the benzodifuran plane. The structure shows a ribbon of molecules oriented along the $b$ axis that stack along the $a$ axis, so that a molecule overlaps two other molecules. The distances between the planes defined by the benzodifuran units are 3.19 and $3.60 \AA$ with many interatomic distances ranging from 3.36 to $3.50 \AA$ as shown by blue dotted lines in Figure 1. This structure demonstrates the strong $\pi-\pi$ stacking between the molecules that allows the development of a bidimensional network of the conjugated systems.

The electronic properties of BDF- $\mathbf{T}_{2}$ have been studied by using cyclic voltammetry and UV-vis spectroscopy (Table 1). The cyclic voltammograms ( $\mathrm{CVs}$ ) of $\mathbf{B D F}-\mathrm{T}_{2}$ in $\mathrm{CH}_{2} \mathrm{Cl}_{2}$ in the presence of $\mathrm{Bu}_{4} \mathrm{NPF}_{6}$ as supporting electrolyte present a reversible oxidation peak at $E_{\mathrm{ox}}=0.99 \mathrm{~V}$ vs SCE and an irreversible reduction peak at $E_{\text {red }}=-1.47 \mathrm{~V}$ (Figures $S 1$ and S2, Supporting Information). By considering the onset of the oxidation and reduction waves, ${ }^{52}$ the calculated HOMO and
LUMO levels are, respectively, -5.87 and $-3.79 \mathrm{eV}$, thus giving an electrochemical gap $\Delta E_{\text {elec }}=2.08 \mathrm{eV}$. These energy levels compared to ones of $\mathrm{C}_{60}$ (HOMO, $-6.00 \mathrm{eV}$; LUMO, -4.20 $\mathrm{eV}$ ) demonstrate the aptitude of BDF-T $\mathbf{T}_{2}$ to be used as donor material in bilayer BDF-T $\mathbf{T}_{2} / \mathrm{C}_{60}$ solar cells. ${ }^{53}$

The UV-vis absorption spectra of BDF- $\mathbf{T}_{2}$ in solution and in film are presented in Figure 2. The spectrum of BDF- $\mathbf{T}_{2}$ in

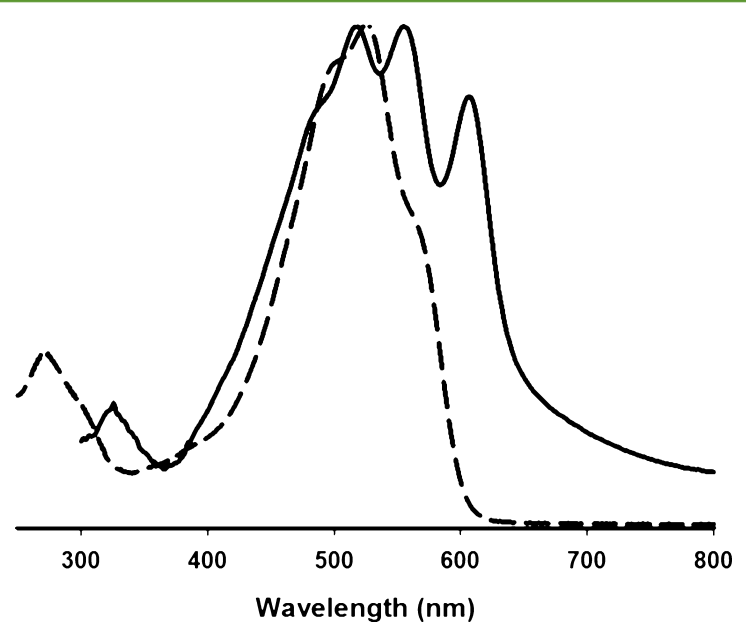

Figure 2. Normalized UV-vis absorption spectra of BDF-T $\mathbf{T}_{2}$ in solution (dotted line) and in film (solid line).

$\mathrm{CH}_{2} \mathrm{Cl}_{2}$ shows a well-structured absorption band with a $\lambda_{\max }$ at $527 \mathrm{~nm}\left(\varepsilon=71000 \mathrm{~L} \mathrm{~mol}^{-1} \mathrm{~cm}^{-1}\right)$ and shoulders at 570 and $490 \mathrm{~nm}$. Films of BDF-T $\mathbf{T}_{2}$ have been deposited on glass by the spin-coating technique using chloroform as solvent. The UVvis absorption spectrum of the film shows a structured absorption band with the presence of three maxima at 512, 590 , and $620 \mathrm{~nm}$ and a shoulder at $490 \mathrm{~nm}$. The absorption band is broader and red shifted compared to the spectrum in solution with the optical band gap of the compound decreasing from $2.1 \mathrm{eV}$ in solution to $1.8 \mathrm{eV}$ in film. 
Table 2. Photovoltaic Characteristics of PHJ Cells Based on Donor BDF-T 2 under AM 1.5-Simulated Solar Illumination at 90 $\mathrm{mW} \mathrm{cm}^{-2}$

\begin{tabular}{cccccc} 
cells & optical density & $V_{\text {oc }}(\mathrm{V})$ & $J_{\text {SC }}\left(\mathrm{mA} \mathrm{cm}^{-2}\right)$ & FF (\%) & PCE (\%) \\
C1 & 0.352 & 0.65 & 2.44 & 27 & 0.46 \\
C2 & 0.279 & 0.67 & 2.31 & 27 & 0.41 \\
C3 & 0.247 & 0.61 & 3.62 & 33 & 0.81 \\
C4 & 0.195 & 0.66 & 4.01 & 40 & 1.18 \\
\hline
\end{tabular}

BDF- $\mathbf{T}_{2}$ has been used as the donor material in basic bilayer planar heterojunction solar cells $(\mathrm{PHJ})$. The cells of $0.28 \mathrm{~cm}^{2}$ area were fabricated using the classical procedure. On ITO substrates precoated by a $40 \mathrm{~nm}$ layer of PEDOT:PSS, the donor layer was spun cast from a chloroform solution $\left(10^{-2}\right.$ mol L ${ }^{-1}$ ) with various speeds obtaining films with different thicknesses leading to several optical densities. Then a $30 \mathrm{~nm}$ layer of $\mathrm{C}_{60}$ was deposited by thermal evaporation under vacuum, and the devices were completed by vacuum deposition of a $100 \mathrm{~nm}$ aluminum electrode. Annealing tests of the films have been performed at different temperatures. The best results were obtained when the films were annealed at $135{ }^{\circ} \mathrm{C}$ for 15 min. The electrical characteristic of the solar cells under AM 1.5-stimulated solar irradiation at $90 \mathrm{~mW} \mathrm{~cm}^{-2}$ are gathered in Table 2. All the cells present a photovoltaic effect with an open circuit voltage $\left(V_{\mathrm{oc}}\right)$ about $0.6 \mathrm{~V}$. The current density $\left(J_{\mathrm{SC}}\right)$ and the fill factor (FF) are strongly thickness dependent on the deposited films. The best performance of the devices is obtained with smaller thicknesses of about 20-25 nm (cell $\mathrm{C} 4$ ). Figure 3 shows the current voltage of cell $\mathrm{C} 4$. The cell

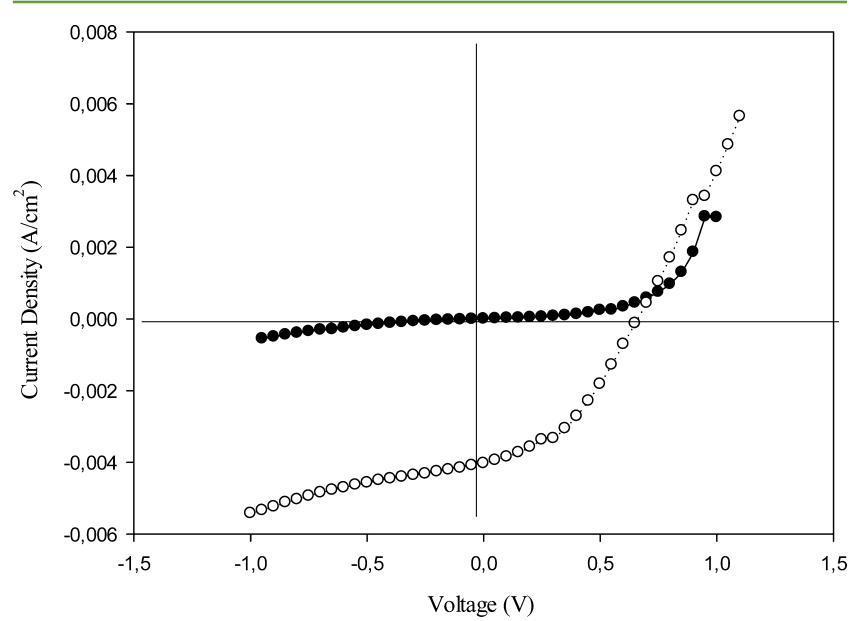

Figure 3. Current density vs voltage curves for bilayer cell BDF-T $\mathbf{T}_{2} /$ $\mathrm{C}_{60}$. Black circles: in the dark. Open circles: under white illumination at $90 \mathrm{~mW} \mathrm{~cm}{ }^{-2}$.

gave a $V_{\text {oc }}$ of $0.66 \mathrm{~V}$ and a $J_{S C}$ of $4.0 \mathrm{~mA} \mathrm{~cm}^{-2}$ combined with a FF of 0.40 , thus leading to a power conversion efficiency (PCE) of $1.18 \%$.

To our knowledge, this result is the first example of small molecules obtained from green chemistry concepts capable of producing a substantial photocurrent. It is also the first demonstration that an azomethine derivative is able to produce solar cells with non-negligible PCE. For copolymers based on $\mathrm{BDF}$ units, the best results in the range of $4-6 \%$ are obtained with bulk heterojunction cells with $\mathrm{PC}_{71} \mathrm{BM}$ and active surfaces of $4 \mathrm{~mm}^{2}{ }^{35,36,38}$ The cell type and active surface have a strong influence on the efficiency of the cells, where the efficiency generally increases when the surface decreases. ${ }^{54}$ Thus, it must be taken in consideration that the evaluation has been done with basic bilayer cells obtained from $\mathrm{C}_{60}$ without any additive materials and by using a relatively large active area $\left(28 \mathrm{~mm}^{2}\right)$.

\section{CONCLUSION}

In conclusion, we have shown that simple and easy to produce conjugated material based on BDF units and azomethine junctions may constitute a green platform for the development of donor molecules for organic photovoltaic cells. Furthermore the structural modification of the materials to optimize energy levels, light harvesting, and charge transport properties can be performed by simple modifications of starting materials with nitrile and aldehyde groups. In order to enhance the green character of the synthesis, several ways are envisaged: (i) modification of the nitrile derivatives by replacing the pentafluorophenyl unit by simpler acceptor groups and (ii) optimization of the synthetic procedures for the preparation of aldehyde derivatives. Work along these directions and on the optimization of solar cells are underway in our group and will be reported in future publications.

\section{ASSOCIATED CONTENT}

S Supporting Information

Calculation of the E factor for BDF-T $\mathbf{T}_{2}$ and compound 4, cyclic voltammogram of BDF-T 2 X-ray data of compound BDF-T . $_{2}$ This material is available free of charge via the Internet at http://pubs.acs.org.

\section{AUTHOR INFORMATION}

\section{Corresponding Author}

* Fax: +33 2417354 05. E-mail: pierre.frere@univ-angers.fr. Notes

The authors declare no competing financial interest.

\section{ACKNOWLEDGMENTS}

We thank Angers Loire Métropole for the fellowship accorded for the Ph.D. of C. Moussallem and Région Pays de la Loire for financial support accorded to the Green-SCO project.

\section{REFERENCES}

(1) Cook, T. R.; Dogutan, D. K.; Reece, S. Y.; Surendranath, Y.; Teets, T. S.; Nocera, D. G. Solar Energy supply and storage for the legacy and nonlegacy worlds. Chem. Rev. 2010, 110, 6474-6502.

(2) Krebs, F. C.; Espinosa, N.; Hösel, M.; Søndergaard, R. R.; Jørgensen, M. 25th Anniversary Article: Rise to power - OPV-based solar parks. Adv. Mater. 2014, No. 26, 29-39.

(3) Kippelen, B.; Bredas, J.-L. Organic photovoltaics. Energy Environ. Sci. 2009, 2, 251-261.

(4) Dou, L.; You, J.; Hong, Z.; Xu, Z.; Li, G.; Street, R. A.; Yang, Y. 25th Anniversary Article: A decade of organic/polymeric photovoltaic research. Adv. Mater. 2013, 25, 6642-6671.

(5) Mishra, A.; Bäuerle, P. Small molecule organic semiconductors on the move: Promises for future solar energy technology. Angew. Chem., Int. Ed. 2012, 51, 2020-2067. 
(6) Walker, B.; Kim, C.; Nguyen, T.-Q. Small molecule solutionprocessed bulk heterojunction solar cells. Chem. Mater. 2011, 23, 470482.

(7) Cheng, Y.-J.; Yang, S.-H.; Hsu, C.-S. Synthesis of conjugated polymers for organic solar cell applications. Chem. Rev. 2009, 109, 5868 .

(8) Nikiforov, M. P.; Lai, B.; Chen, W.; Chen, S.; Schaller, R. D.; Strzalka, J.; Maser, J.; Darling, S. B. Detection and role of trace impurities in high-performance organic solar cells. Energy Environ. Sci. 2013, 6, 1513-1520.

(9) Osedach, T. P.; Andrew, T. L.; Bulovic, V. Effect of synthetic accessibility on the commercial viability of organic photovoltaics. Energy Environ. Sci. 2013, 6, 711-718.

(10) Burke, D. J.; Lipomi, D. J. Green chemistry for organic solar cells. Energy Environ. Sci. 2013, 6, 2053-2066.

(11) Berrouard, P.; Najari, A.; Pron, A.; Gendron, D.; Morin, P.-O.; Pouliot, J.-R.; Veilleux, J.; Leclerc, M. Synthesis of 5-alkyl[3,4c] thienopyrrole-4,6-dione-based polymers by direct heteroarylation. Angew. Chem., Int. Ed. 2012, 51, 2068-2071.

(12) Mercier, L. G.; Leclerc, M. Direct (hetero)arylation: A new tool for polymer chemists. Acc. Chem. Res. 2013, 46, 1597-1605.

(13) Schipper, D. J.; Fagnou, K. Direct arylation as a synthetic tool for the synthesis of thiophene-based organic electronic materials. Chem. Mater. 2011, 23, 1594-1600.

(14) Durso, M.; Bettini, C.; Zanelli, A.; Gazzano, M.; Lobello, M. G.; De Angelis, F.; Biondo, V.; Gentili, D.; Capelli, R.; Cavallini, M.; Toffanin, S.; Muccini, M.; Melucci, M. Synthesis, size-dependent optoelectronic and charge transport properties of thieno(bis)imide end-substituted molecular semiconductors. Org. Electron. 2013, 14, 3089-3097.

(15) Ho, H. A.; Brisset, H.; Elandaloussi, E. H.; Frère, P.; Roncali, J. Thiophene-based conjugated oligomers and polymers with high electron affinity. Adv. Mater. 1996, 8, 990-994.

(16) Colladet, K.; Fourier, S.; Cleij, T. J.; Lutsen, L.; Gelan, J.; Vanderzande, D.; Huong Nguyen, L.; Neugebauer, H.; Sariciftci, S.; Aguirre, A.; Janssen, G.; Goovaerts, E. Low band gap donor-acceptor conjugated polymers toward organic solar cells applications. Macromolecules 2007, 40, 65-72.

(17) Kim, J. H.; Chung, J. W.; Jung, Y.; Yoon, S.-J.; An, B.-K.; Huh, H. S.; Lee, S. W.; Park, S. Y. High performance n-type organic transistors based on a distyrylthiophene derivative. J. Mater. Chem. 2010, 20, 10103-10106.

(18) An, B.-K.; Gierschner, J.; Park, S. Y. Pi-conjugated cyanostilbene derivatives: A unique self-assembly motif for molecular nanostructures with enhanced emission and transport. Acc. Chem. Res. 2012, 45, 544554.

(19) Yang, C. J.; Jenekhe, S. A. Conjugated aromatic poly(azomethines). 1. Characterization of structure, electronic spectra, and processing of thin films from soluble complexes. Chem. Mater. 1991, 3, 878-887.

(20) Bolduc, A.; Al Ouahabi, A.; Mallet, C.; Skene, W. G. Insight into the isoelectronic character of azomethines and vinylenes using representative models: A spectroscopic and electrochemical study. J. Org. Chem. 2013, 78, 9258-9269.

(21) Bolduc, A.; Dufresne, S.; Skene, W. G. EDOT-containing azomethine: an easily prepared electrochromically active material with tuneable colours. J. Mater. Chem. 2010, 20, 4820-4826.

(22) Tshibaka, T.; Bishop, S.; Roche, I. U.; Dufresne, S.; Lubell, W. D.; Skene, W. G. Conjugated 4-methoxybipyrrole thiophene azomethines: Synthesis, opto-electronic properties, and crystallographic characterization. Chem.-Eur. J. 2011, 17, 10879-10888.

(23) Barik, S.; Bletzacker, T.; Skene, W. G. Pi-conjugated fluorescent azomethine copolymers: Opto-electronic, halochromic, and doping properties. Macromolecules 2012, 45, 1165-1173.

(24) Mallet, C.; Le Borgne, M.; Starck, M.; Skene, W. G. Unparalleled fluorescence of a polyazomethine prepared from the self-condensation of an automer and its potential use as a fluorimetric sensor for explosive detection. Polym. Chem. 2013, 4, 250-254.
(25) Schwab, M. G.; Hamburger, M.; Feng, X.; Shu, J.; Spiess, H. W.; Wang, X.; Antonietti, M.; Mullen, K. Photocatalytic hydrogen evolution through fully conjugated poly(azomethine) networks. Chem. Commun. 2010, 46, 8932-8934.

(26) Iwan, A.; Palewicz, M.; Chuchmala, A.; Gorecki, L.; Sikora, A.; Mazurek, B.; Pasciak, G. Opto(electrical) properties of new aromatic polyazomethines with fluorene moieties in the main chain for polymeric photovoltaic devices. Synth. Met. 2012, 162, 143-153.

(27) Petrus, M. L.; Bouwer, R. K. M.; Lafont, U.; Murthy, D. H. K.; Kist, R. J. P.; Bohm, M. L.; Olivier, Y.; Savenije, T. J.; Siebbeles, L. D. A.; Greenham, N. C.; Dingemans, T. J. Conjugated poly(azomethine)s via simple one-step polycondensation chemistry: Synthesis, thermal and optoelectronic properties. Polym. Chem. 2013, 4, 4182-4191.

(28) Hayashi, N.; Saito, Y.; Higuchi, H.; Suzuki, K. Comparative studies on electronic spectra and redox behaviors of isomeric

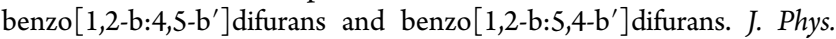
Chem. A 2009, 113, 5342-5347.

(29) Mitsui, C.; Tsuji, H.; Sato, Y.; Nakamura, E. Carbazolyl benzo[1,2-b:4,5-b']difuran: An ambipolar host material for full-color organic light-emitting diodes. Chem. Asian J. 2012, 7, 1443-1450.

(30) Mitsui, C.; Tanaka, H.; Tsuji, H.; Nakamura, E. Bis(carbazolyl)benzodifuran has a high triplet energy level for application in blue phosphorescent OLED. Chem. Asian J. 2011, 6, 2296-2300.

(31) Tsuji, H.; Mitsui, C.; Sato, Y.; Nakamura, E. Bis(carbazolyl)benzodifuran: A high-mobility ambipolar material for homojunction organic light-emitting diode devices. Adv. Mater. 2009, 21, 37763779.

(32) Tsuji, H.; Mitsui, C.; Ilies, L.; Sato, Y.; Nakamura, B. Synthesis and properties of 2,3,6,7-tetraarylbenzo[1,2-b: 4,5-b' $\left.\mathrm{b}^{\prime}\right]$ difurans as holetransporting material. J. Am. Chem. Soc. 2007, 129, 11902-11903.

(33) Li, H.; Jiang, P.; Yi, C.; Li, C.; Liu, S. X.; Tan, S.; Zhao, B.; Braun, J.; Meier, W.; Wandlowski, T.; Decurtins, S. Benzodifuranbased pi-conjugated copolymers for bulk heterojunction solar cells. Macromolecules 2010, 43, 8058-8062.

(34) Li, H.; Tang, P.; Zhao, Y.; Liu, S. X.; Aeschi, Y.; Deng, L.; Braun, J.; Zhao, B.; Liu, Y. Q.; Tan, S.; Meier, W.; Decurtins, S. Benzodifurancontaining well-defined pi-conjugated polymers for photovoltaic cells. J. Polym. Sci., Part A: Polym. Chem. 2012, 50, 2935-2943.

(35) Huo, L.; Huang, Y.; Fan, B.; Guo, X.; Jing, Y.; Zhang, M.; Li, Y.; Hou, J. Synthesis of a 4,8-dialkoxy-benzo[1,2-b:4,5-b'] difuran unit and its application in photovoltaic polymer. Chem. Commun. 2012, 48, $3318-3320$.

(36) Huo, L. J.; Ye, L.; Wu, Y.; Li, Z. J.; Guo, X.; Zhang, M. J.; Zhang, S. Q.; Hou, J. H. Conjugated and nonconjugated substitution effect on photovoltaic properties of benzodifuran-based photovoltaic polymers. Macromolecules 2012, 45, 6923-6929.

(37) Huo, L.; Li, Z.; Guo, X.; Wu, Y.; Zhang, M.; Ye, L.; Zhang, S.; Hou, J. Benzodifuran-alt-thienothiophene based low band gap copolymers: substituent effects on their molecular energy levels and photovoltaic properties. Polym. Chem. 2013, 4, 3047-3056.

(38) Liu, B.; Chen, X.; Zou, Y.; Xiao, L.; Xu, X.; He, Y.; Li, L.; Li, Y. Benzo[1,2-b:4,5- $\left.\mathrm{b}^{\prime}\right]$ difuran-based donor-acceptor copolymers for polymer solar cells. Macromolecules 2012, 45, 6898-6905.

(39) Liu, B.; Chen, X.; Zou, Y.; He, Y.; Xiao, L.; Xu, X.; Li, L.; Li, Y. A benzo[1,2-b:4,5- $\left.\mathrm{b}^{\prime}\right]$ difuran- and thieno-[3,4-b]thiophene-based low bandgap copolymer for photovoltaic applications. Polym. Chem. 2013, $4,470-476$

(40) Sista, P.; Huang, P.; Gunathilake, S. S.; Bhatt, M. P.; Kularatne, R. S.; Stefan, M. C.; Biewer, M. C. Synthesis and optoelectronic properties of novel benzodifuran semiconducting polymers. J. Polym. Sci., Part A: Polym. Chem. 2012, 50, 4316-4324.

(41) Zhang, Y.; Gao, L.; He, C.; Sun, Q. J.; Li, Y. F. Synthesis and photovoltaic properties of two-dimension-conjugated D-A copolymers based on benzodithiophene or benzodifuran units. Polym. Chem. 2013, 4, 1474-1481.

(42) Anastas, P.; Eghbali, N. Green chemistry: Principles and practice. Chem. Soc. Rev. 2010, 39, 301-312.

(43) Moussallem, C.; Gohier, F.; Mallet, C.; Allain, M.; Frère, P. Extended benzodifuran-furan derivatives as example of pi-conjugated 
materials obtained from sustainable approach. Tetrahedron 2012, 68, $8617-8621$.

(44) Kim, K. H.; Chi, Z.; Cho, M. J.; Jin, J.-I.; Cho, M. Y.; Kim, S. J.; Joo, J.-S.; Choi, D. H. Soluble star-shaped molecules based on thiophene derivatives as organic semiconductors for field-effect transistor applications. Chem. Mater. 2007, 19, 4925-4932.

(45) Kirkus, M.; Wang, L.; Mothy, S.; Beljonne, D.; Cornil, J.; Janssen, R. A. J.; Meskers, S. C. J. Optical properties of oligothiophene substituted diketopyrrolopyrrole derivatives in the solid phase: Joint Jand H-type aggregation. J. Phys. Chem. A 2012, 116, 7927-7936.

(46) Sheldrick, G. M. SHELX97. Acta Cryst. 2008, A64, 112-122.

(47) Sheldrick, G. M. SADABS; University of Göttingen: Göttingen, Germany, 2008.

(48) Bennett, J. S.; Charles, K. L.; Miner, M. R.; Heuberger, C. F.; Spina, E. J.; Bartels, M. F.; Foreman, T. Ethyl lactate as a tunable solvent for the synthesis of aryl aldimines. Green Chem. 2009, 11, 166168.

(49) Pereira, C. S. M.; Silva, V. M. T. M.; Rodrigues, A. E. Ethyl lactate as a solvent: Properties, applications and production processes a review. Green Chem. 2011, 13, 2658-2671.

(50) Sheldon, R. A. The E Factor: Fifteen years on. Green Chem. 2007, 9, 1273-1283.

(51) Sheldon, R. A. E factors, green chemistry and catalysis: An odyssey. Chem. Commun. 2008, 3352-3365.

(52) Cardona, C. M.; Li, W.; Kaifer, A. E.; Stockdale, D.; Bazan, G. C. Electrochemical considerations for determining absolute frontier orbital energy levels of conjugated polymers for solar cell applications. Adv. Mater. 2011, 23, 2367-2371.

(53) Schlenker, C. W.; Thompson, M. E. The molecular nature of photovoltage losses in organic solar cells. Chem. Commun. 2011, 47, 3702-3716.

(54) Anctil, A.; Babbitt, C. W.; Raffaelle, R. P.; Landi, B. J. Cumulative energy demand for small molecule and polymer photovoltaics. Prog. Photovoltaics 2013, 21, 1541-1554. 